\title{
Geology, the regulated discipline and profession in Europe
}

\author{
${ }^{1}$ Joint Research Centre, European Commission, 21027 Ispra (VA), Italy; *Corresponding author, E-mail: tamas.hamor@ec.europa.eu \\ ${ }^{2}$ University of Pécs, 7624, Baranya, Hungary \\ ${ }^{3}$ International Raw Materials Observatory, Brussels, Belgium
}

(Received: November 4, 2019; Revised accepted: August 13, 2020)

https://doi.org/10.18814/epiiugs/2020/020075

Geological aspects and the related duties of geologists are embedded into numerous sector-specific legislation of the European Union and its legal predecessors. In a broad sense, geology-related topics make up about 10-15\% of EU legal documents. The founding treaties of the European Coal and Steel Community and Euratom provide rules related mainly to the fossil fuels extractive industry. In the last decade of the twentieth century, environment, water and waste management regulatory fields entered the Community domain, along with geological issues. Energy policy, de-carbonization, raw materials policy and the circular-economy concept generated numerous new tasks for geoscientists over the last twenty years. The Professional Qualifications Directive acknowledges geology as a regulated profession, it facilitates the mobility of geologists across Member States, and, together with the codification of geoscientists' work, drives geoscience professionalism in Europe.

\section{Introduction}

A number of reviews and foresight reports were published on the role of geologists in the context of sustainable development and emerging policy fields (e.g., Cordiani, 2000; Vidal et al., 2013; VERAM Roadmap, 2018). A few publications deal with the assessment of the EU Community law with regard to specific topics such as soil (Hamor, 2004), geothermal energy (Goodman et al., 2010; Toth, 2017), mineral extractive waste (Hamor, 2002), mining and permitting (Hamor, 2004; EC, 2017), and unconventional hydrocarbons (Mitchell et al., 2016). Recently, EuroGeoSurveys, the network of EU Member States' (hereinafter: MS) national geological services, identified research areas related to the use of subsurface in frame of the GeoERA project (https://geoera.eu).

Geology is a cross-over discipline. Its findings are used in many sectors of economy, such as raw materials, energy and water supply, environmental management, climate change and de-carbonisation, spatial planning and construction operations, geospace use, geohazards mitigation, forensic and defence geology. A good indicator of geology's importance is that geologists are employed across a wide spectrum of the academic, governmental, and private spheres. As a consequence, authors address ethical principles, certification and performance rules of professional geologists (e.g., Allington - Fernandez-Fuentes, 2014). Nevertheless, not much attention was paid to how this discipline and profession is regulated at the national, international, and supranational scale.

This paper reviews the evolution of EU Community legislation over the last half century, with regard to provisions on geology-related fields. The most important pieces are listed in the Annex. A quantitative approach is provided by a terminology search in the database of the EU legal documents "EUR-LEX" (https://eur-lex.europa.eu/homepage.html). The paper concludes with the authors' assessment of the major historical trends in professional legislation and a discussion of its future outlook.

\section{Methodology}

The historical review is partly based on the works of Hamor (2002, 2004a, 2004b, 2014, 2016), the European Commission (2017), Goodman et al. (2010), Mitchell et al. (2016), and on the list of EU secondary legislation in the EU Raw Materials Information System (Manfredi et al., 2017). For recent pieces of legislation the Official Journal of the European Union (2020) was monitored.

For a quantitative trend analysis, the advanced search functions of the EUR-LEX were used, specifically the "all documents" setting, which includes EU law, international agreements, preparatory documents, parliamentary interpellations, and some of the national law. The text search covered cluster of words (using "OR" option) which are relevant for geology in the strict sense ("geolog", "geophys", "soil", "mineral") and in a broader context ("water", "environment"). It was found that other words can be misleading (e.g. rock/rocket). The examined period is from 1970 until the end of 2019. The total number of documents published annually was also searched for a relative trends comparison. In the case of "geolog", "geophys", "soil", and "mineral" the set of legal acts in a strict sense was also searched, i.e., regulations, directives and decisions.

\section{Introduction to the EU Community law}

Community law ("acquis communautaire") is an independent legal 
system which takes precedence over national legislation, and is often referred to as "supranational" law. Primary legislation includes treaties and agreements with similar status, such as international conventions. Treaties define the thematic scope of the Community law, the responsibilities of decision-making bodies and the legislative, executive and juridical procedures. Secondary legislation takes the form of: (a) regulations, which are directly applicable and binding in all MS; (b) directives, binding as to the objectives to be achieved within a certain timelimit, while leaving to the national authorities the choice of form and means to be used; and (c) decisions, which are binding in all their aspects for those to whom they are addressed. The "acquis" is directly applicable as grounds for justification of an appeal in the courts of all MS.

\section{Results}

\section{Historical Review}

\section{The early decades (1951-1989)}

The fuels extractive industry was a focal economic and legislative field in the early history of the European Community from the beginning (Hamor, 2002). Coal appears in the name of the European Coal and Steel Community, the original predecessor of the EU. One of the objectives of the Rome Treaty (1951) was "to promote a policy of using natural resources rationally and avoiding their unconsidered exhaustion." The Euratom Treaty (1957) established specific provisions concerning raw source material supplies providing a "common supply policy on the principle of equal access". In the 1960-70s, the geology related acquis was restricted to resolutions promoting the extractive sector, directives on stocking and trading of uranium and fossil fuels (Annex 2), mines safety, and occupational health.

The first piece of environmental legislation was the Directive on dangerous substances published in 1967 (Annex 1). In the mid 1970s the first directives appeared in water policy (Annex 3, 5, 6, 7), among which the Groundwater Directive set the most explicit tasks for geologists. In 1982, as a follow-up to the Seveso accident, the Directive on industry accident hazards was published (Annex 8). Soon after that a comprehensive legislation was adopted on environmental impact assessment and permitting methodology, with lists of projects and facilities within its scope (Annex 9). Another environmental compartment, soil, was brought into the scope of the acquis in the context of sewage sludge management and plant protection (Annex 10,16). The Directive on construction affairs also stipulated requirements for mechanical resistance and stability (Annex 11), and paved the way for later EU technical standards (Eurocode7 on geotechnics, Eurocode8 on seismic design).

\section{Growing legitimacy of environment (1990-1999)}

The political transformation of 1989-90 had hardly any direct effect on professional legislation in Europe. Legislation was updated and extended in traditional fields like technical safety and occupational health at drilling, underground mines, and ionizing radiation (Annex $12,20,21,25,28)$. In line with international standards, the statistical system of products was established (Annex 14), including extracted minerals and semi-finished (intermediary) mineral products. The adoption of the Hydrocarbons Directive (Annex 26) was a breakthrough, promoting undistorted open competition in oil and gas exploration and production, while taking into account geological conditions.

Water legislation was further developed for urban waste waters, nitrates, and potable water (Annex 15, 17, 31), as well as for waste policy on hazardous waste, packaging waste, and landfill of waste (Annex 18, 27, 34). The Landfill Directive addressed numerous geological aspects. It acknowledges, for example, the multi-barrier protection concept through the joint performance of geological and engineered barriers working against the migration of pollutants from landfilled waste.

The milestone in the environmental acquis was the Amsterdam Treaty (1997), which implemented a coherent Community policy by adopting the concept of sustainable development and of, inter alia, the "prudent and rational utilisation of natural resources." As a result, beyond the emission- or compartment-specific legislation, a set of socalled "horizontal" legislation was published in the 1990s, such as those addressing access to information, biodiversity, risk assessment methodologies, integrated pollution prevention and control, and accident hazards prevention (Annex 13, 19, 22, 24, 29, 30), but still excluding the extractive sector from the scope of most of the above listed. In addition, the rules on the eligibility of projects for Community funding had references to soil and subsoil conditions (Annex 23, 32, 33).

\section{Widened spectrum for energy, climate and the extractive sector (2000-2009)}

The 21 st century brought significant changes in the acquis with regard to geoscientific aspects both in terms of new topics and the intensity of legislation making. The Annex lists 50-60 pieces for each of the last two decades. A novelty is that the energy field was now covered by the acquis in harmony with the new climate policy. As a result of tailings spills (Aznarcollar 1998, Baia Mare 2000), extractive waste management and the minerals extractive sector in general were brought into the scope of the environmental acquis.

In the energy field the Renewables Directive defined geothermal energy (Annex 42). Its implementing legislation provided details on geothermal power plants and heat pump requirements (Annex 49, 59, $68,75,77,84,88)$. The climate file, as a new entrant, implemented the international treaties on Community scale (Annex 43, 55). It also introduced measures on the geological storage of carbon dioxide (Annex 85), very likely the most geology-specific directive in force. Parallel to this de-carbonisation, the phasing out of the coal industry was regulated (Annex 46, 51).

This decade is characterized by a proliferation of legislation on the environment. The Water Framework Directive was elaborated (Annex 35 ) with a complex management scheme applied to the scale of river basins and integrating groundwater bodies. This generated a need for hydrogeological and hydrological studies at all scales. Its "daughter" pieces comprise references to the most polluting substances, groundwater protection, flood risks assessment, mineral waters and the marine environment (Annex 45, 70, 74, 86, 39, 80).

The "horizontal" environmental legislation extended to an inventory of emissions, voluntary eco-management schemes, public participa- 
tion, environmental liability and the application of criminal law, registration of chemicals, spatial information including mineral and energy commodity resources and geohazards, and the new impact assessment directive (Annex 37, 64, 40, 84, 53, 54, 56, 60, 58, 66, 73, 76, 41). Other relevant legislation addressed the eco-labelling of soil improvers and hard floor covering (Annex 44, 50, 72, 94). These have had a pioneering role in introducing resource (material, water, energy) efficiency considerations and LCA thinking to the acquis. The European adaptation of the Kimberley certification scheme on diamonds (Annex 48 ), and the updated rules on safe supply of crude oil and fissile ores (Annex 87, 63) were also released. The emerging terror threat led to the publication of a directive on the protection of critical infrastructures (Annex 82).

The waste management policy was further developed by substantial pieces on: the European Waste Catalogue and statistics; waste batteries which can be considered the first attempt at regulating productspecific recycling and recovering secondary raw materials; packaging waste; further classification requirements of landfills; the new Waste Framework Directive with definitions of end-of-waste and by-product, quantitative recycling targets for waste streams such as construction and demolition waste, a potential substitute to natural aggregates (Annex 38, 47, 69, 78, 57, 81). In addition, tailings dam failures led to the establishment of a cluster of rules on the extractive waste stream (Annex 67, 89-93), where obligations implicitly require the involvement of professional geologists and include geological aspects.

The Directive on the recognition of professional qualifications and the Regulation on the statistical classification of economic activities provide a framework for the free movement and work of geologists within the EU (Annex 62, 65).

\section{Diversification of policy and regulatory fields, including non-fuel raw materials (2010-2020)}

Community legislation over the last decade is characterized by the further diversification of the regulated fields, the modernization of the existing pieces through amendments, the de-regulation and "smart regulation" campaign, and new policies that have not attained the level of legislation but are represented by numerous Commission Communications addressing unconventional hydrocarbons, non-fuel raw materials, and circular economy.

In the field of energy, the new legislation focuses on infrastructure issues, security of supply, product labelling, energy performance of buildings, energy efficiency, and renewables (Annex 96, 122, 97, 98, 99, 145), with special attention on geothermal heat pumps (Annex $111,113,119,147)$. International accidents in the offshore oil and gas sector generated particular measures (Annex 115, 118, 124).

The climate package was updated regarding emission accounting, CCS, and risky sectors (Annex 120, 141, 145), along with a decision on facilitating the closure of uncompetitive coal mines (Annex 101).

The environment dossier received substantially amended pieces on the EIA, Seveso, the Industrial Emissions Directive replacing IPPC, the new Action Programme, and new ecolabel standards (Annex 105, $100,109,121,95,129,142)$. The priority in water policy was on the marine environment (Annex 128, 134, 139, 140).

The waste acquis made progress with the ban on mercury, the amendment of the framework directive and the landfill rules, and a directive on plastics (Annex 137, 144, 143, 148). The implementation focus of the framework directive was on end-of-waste and recycling specifications (Annex 103, 107, 108, 110, 112), and defining exotoxicity in details (Annex 138). The long-awaited piece on radioactive waste management was approved (Annex 104).

The last decade brought the modernization of the raw materials sector. The Raw Materials Initiative (RMI; EC, 2008) was the document establishing this policy field. Its three pillars are (a) access to resources in third countries, (b) fostering sustainable supply from EU domestic sources, and (c) boosting resource efficiency and recycling.

The measures related to the international pillar reached the level of Community legislation by adopting the OECD due diligence standard on conflict minerals (Annex 136, 146), as well as the third pillar on secondary raw materials covered by the waste acquis (Annex 103, $107,108,110,112$ ). Similar efforts on regulating the domestic pillar met the opposition of MS wishing to keep management of this natural asset within their sovereign jurisdiction. As a result, the list of critical raw materials, the Resource Efficiency Roadmap, and the European Innovation Partnership on Raw Materials were published (EC, 2011a,b, 2012, 2013, 2014c). Parallel to and partly overlapping with this field, the circular economy concept evolved but also remained at the level of communications (EC, 2014d, 2015, 2017a,b,c, 2018).

The US shale gas boom did not generate precautionary measures among EU policy makers, in spite of numerous exploration projects launched in Poland, Hungary, Romania and the UK. The sector came into political focus in 2011 when France introduced a ban on hydraulic fracturing. The Commission and the Parliament published several reports, and a Communication and a Recommendation in 2014, both covering geological aspects (EC, 2014a,b). A specific BREF (Best Available Techniques (BAT) Reference document) is in preparation.

The introduction of codes of practice in many areas of geosciences has raised the level of responsibility of geologists toward society. Geoscientists are now called to provide advice on the management of natural resources, on environmental protection and on the dynamics of natural systems (Peppoloni and Capua, 2017). This requires competence, framed by ethical values.

\section{The Green Deal $(2020$ - ...)}

In December 2019 The European Green Deal, the new growth strategy was published by the European Commission (EC, 2019). It aims to transform the EU into a fair and prosperous society, with competitive economy where there are no net emissions of greenhouse gases in 2050 and where economic growth is decoupled from resource use. Resource-efficiency, circular economy, de-carbonization, toxic-free environment, clean and secure energy are central constituents of the strategy which integrates all these policies into a coherent societal and economic agreement.

Geoscientific knowledge needs are embedded in several key pillars, such as clean energy, smart mobility, climate ambition, fostering innovation. Raw materials are dealt with under "Mobilising industry for a clean and circular economy" which points at that only $12 \%$ of the materials use comes from recycling. It calls for actions on resourceintensive industry sectors, waste reduction, establishing a robust and integrated single market for secondary raw materials and by-products. It acknowledges that access to resources is a strategic security 
question. Ensuring the sustainable supply of raw materials, in particular of critical raw materials necessary for clean technologies, digital, space and defence applications, by diversifying supply from both primary and secondary sources, is one of the pre-requisites to make the green transition happen.

\section{Regulating Professional Geologists}

The Directive on recognition of professional qualifications (Annex 62) has precursors dating back to 1964 . Its major objective is to ensure the free movement of persons and services for nationals of the MS, in particular the right to pursue a profession, in a self-employed or employed capacity, in a MS other than the one in which they obtained their professional qualifications. It covers both temporary and permanent employment.

According to Article 3, a regulated profession is a "professional activity or group of professional activities, access to which, the pursuit of which, or one of the modes of pursuit of which is subject, directly or indirectly, by virtue of legislative, regulatory or administrative provisions to the possession of specific professional qualifications; in particular, the use of a professional title limited by legislative, regulatory or administrative provisions to holders of a given professional qualification shall constitute a mode of pursuit. Where the first sentence of this definition does not apply, a profession referred to in paragraph 2 shall be treated as a regulated profession". Paragraph 2 refers to professions practised by the members of an association listed in Annex I, such as, for example, the Institution of Mining Engineers.

There are three systems for the recognition of qualifications:

- automatic recognition for professions for which the minimum training conditions are harmonised in details (health professionals, architects, etc. listed in Annex V);

- a general system for other regulated professions;

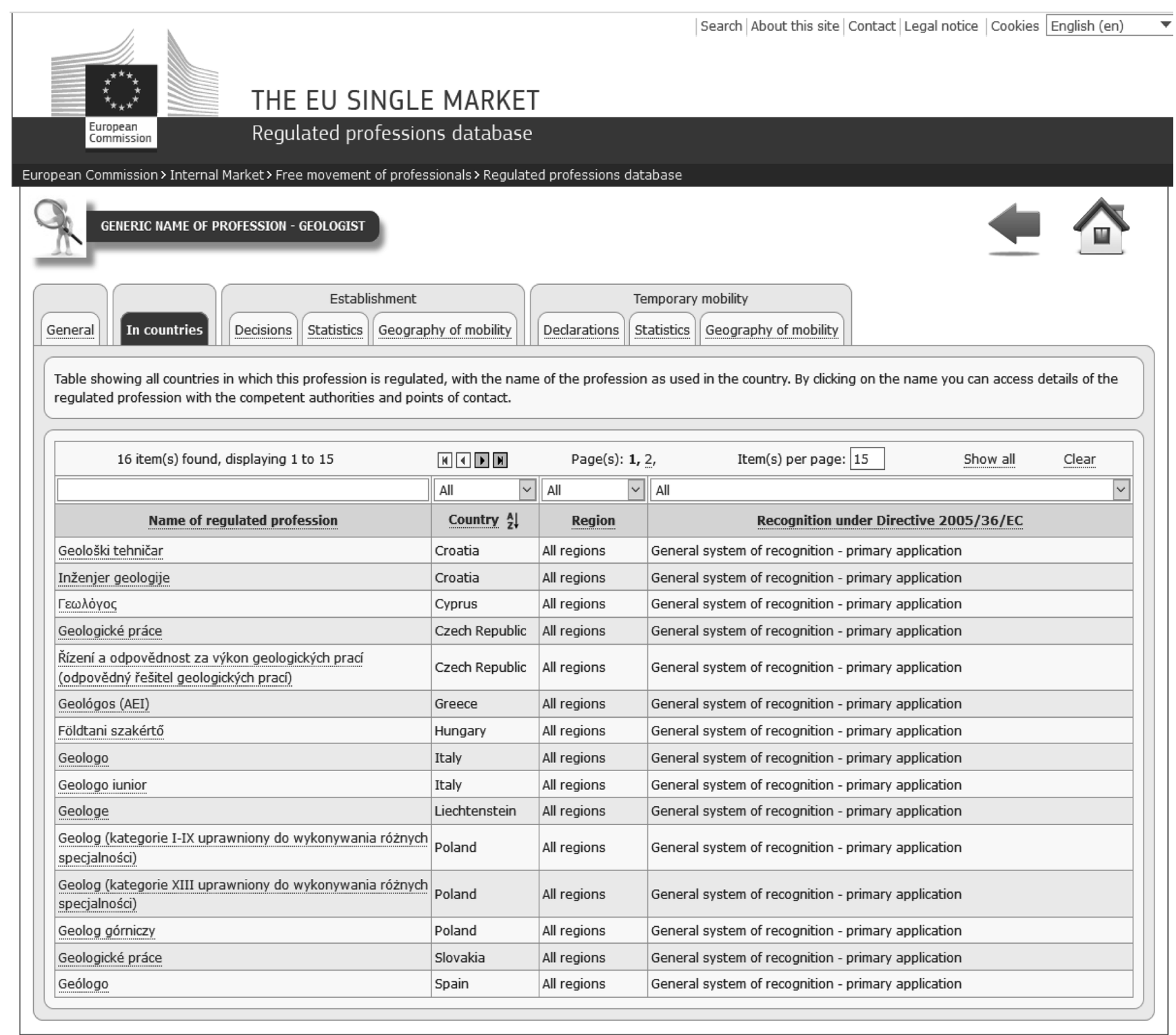

The database contains information on regulated professions, statistics on migrating professionals, contact points and competent authorities, as provided by EU Member States, EEA countries and Switzerland. Each country is responsible for updating information, on its regulated professions, competent authorities and statistics.

The Commission cannot be held responsible for the accuracy of the information. However, if errors are brought to its attention, the Commission undertakes to correct them, if deemed appropriate.

Figure 1. Regulated geologist titles in MS registered in the EU database. 
- recognition on basis of professional experience.

The general system describes 5 levels of qualifications (Art. 11):

a) training course without a diploma, or 3 years full-time pursuit of profession;

b) secondary course with a certificate (e.g., geological technician);

c) post-secondary training or regulated education with diploma;

d) 3-4 years university course with diploma (e.g., BSc geologist);

e) minimum 4 years university course with diploma (e.g., MSc geologist).

Articles 12 and 13 prescribe how these shall be mutually acknowledged, without specific details regarding the geologist diploma.

Chapter II regulates the recognition of the professional experience, the third system for activities in Annex IV. The relevant entries to geologists are "320 Petroleum industry" and " 33 Manufacture of nonmetallic mineral products", and " 40 Construction".

When selecting the term "geologist" in the EU database (https:// ec.europa.eu/growth/tools-databases/regprof), 16 titles of 12 countries pop up (the $16^{\text {th }}$ UK is not displayed in Fig. 1). Among these, geologist technicians also appear in Croatia and Italy. All are indicated as belonging to the second, general system. The database also displays chartered (certified) geologists under the general system which requires professional experience. The database registered 99 applications for establishment of which 5 were rejected, and 104 cases for temporary permit, all accepted. It shows that overall cross-country mobility of geologists in the EU is well below $1 \%$, even taking into account that a good number of cases are not registered in the system because many do not need this administrative recognition.

According to the Preamble, "various professional associations ... should be able to propose common platforms at European level, ... these criteria could, for example, include requirements such as additional training, an adaptation period under supervised practice, an aptitude test, or a prescribed minimum level of professional practice, or combinations thereof." In accordance, Article 52 "Use of professional titles" provides mandate for national and pan-European associations to act for registration their titles.

The recognition of geoscience professional titles and qualifications in Europe is being enabled by the European Federation of Geologists (EFG) for more than two decades. This might explain the low numbers of geologists with cross-country mobility in the EU database. Pursuant to Directive $89 / 48 / \mathrm{EEC}$ on a general system for the recognition of higher-education diplomas awarded on completion of professional education and training of at least three years' duration and Directive 92/51/EEC on a second general system for the recognition of professional education and training, EFG adopted in 1993 a system of multilateral recognition of qualifications between affiliated geological associations, levelling different regulatory frameworks concerning the professional practice.

The EFG system is based on a voluntary professional title, named EurGeol, awarded to geoscience professionals who have the knowledge, experience, skills and competence to deliver high-quality services within the practice of geology (Clifford, 2002; Allington - FernandezFuentes, 2014). Applicants must 1) have followed and satisfactorily completed an educational programme at the university level in geology or a related subject and have been awarded a degree or equivalent qualification; 2) demonstrate that they have obtained sufficient knowledge and experience, over a combined minimum total of nine years (education and professional practise combined), to be able to work independently and to be capable of supervising others; 3 ) abide the Code of Ethics established by the EFG; and 4) commit to the systematic maintenance, improvement and broadening of knowledge and skills and the development of personal qualities necessary for the execution of professional and technical duties.

Applicants are recommended by their National Association and accepted by EFG before they are awarded the EurGeol title (https:// eurogeologists.eu/eurgeol-title).

Beyond Europe, the EurGeol title is recognised in Australia, Canada, Chile, the US and South Africa through a mutual recognition of qualifications system established between 26 Recognised Professional Organisations (RPOs; Stoker, 2014). These RPOs:

a) are independent and self-regulated, representing geoscience professionals active in a sector or industry;

b) admit members primarily based on their academic qualifications and professional experience;

c) require compliance with the professional standards of competence and ethics, established by the organisation, anywhere in the world; and

d) have disciplinary powers, including the ability to suspend or expel a member for breaches of professional standards of competence or ethics anywhere in the world.

\section{Quantitative Analysis}

The visualization of the number of documents in the EUR-LEX database with regard to words specific to geosciences is provided on Fig. 2. The vertical axis is in a logarithmic scale in order to accommodate the two to five digit extremes. The total number of all legal documents has been steadily increasing in the last half century until 2014, when the Juncker Commission took office and launched a deregulation program. From the peak of 27,632 in 2013 the annual publications reduced to half. The 4-6 years periodicity of negative shifts in the curve (e.g., 1989, 1994, 1999, 2004, 2009) are due to the phasing out of the old and taking over by the new European Commission and the Parliament. The enlargements of the Community (1973, 1981, 1986, $1995,2004,2007,2013)$ do not have visible effects on legislation, beyond the overall increasing trend.

The number of documents with the words "water" + "environment" show a historical trend similar to the number of documents with the words "geology" + "soil" + "geophys" + "mineral" since the 1990s, the latter having ca. 5-6 times less, 400-700 as compared to 2000-3000 for the previous. As shown in the historical review above, this trend is due to the Amsterdam Treaty (1997) and the resulting development of the environmental acquis.

The number of strictly legal texts with words "geology" + "soil" + "geophys" + "mineral" is indicative of how frequently this sector is dealt with by legislators. In the mid 1970s this number more or less equals that of all documents with these words, as well as that of all documents with "water" + "environment". The separation of the three curves start in the 1980s. Since the mid 1990s their relative proportions remain stable whilst all have been increasing until 2018, even over the last five years deregulation period.

An obvious observations is that the number of legal documents with topics explicitly or implicitly relevant to geology has been increasing 


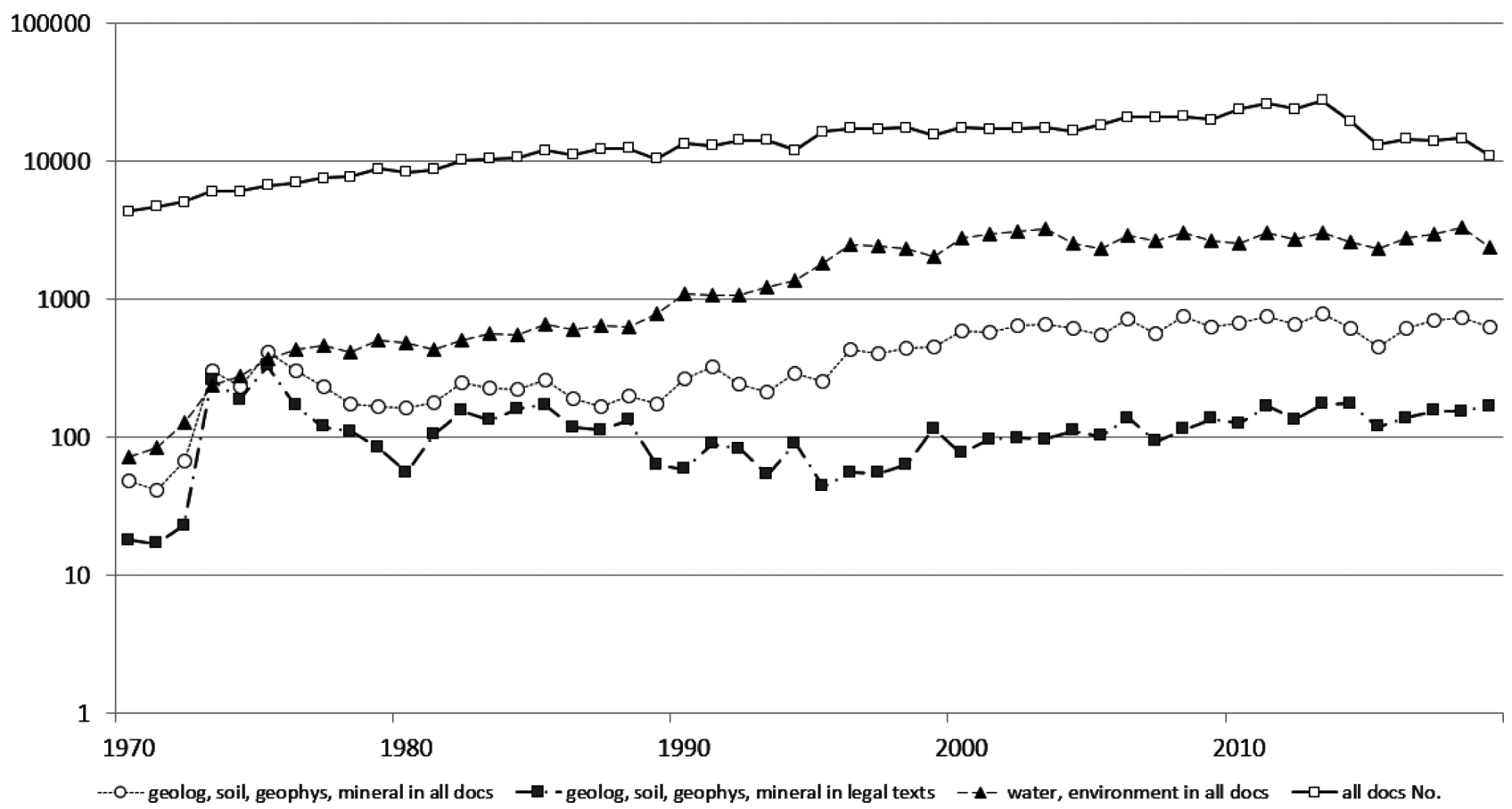

Figure 2. The number of annually (1970-2019) published legal documents in the European Union and in relation to environment and geology, as a result of a text search in the EUR-LEX on-line database

during the last half century and also relative to the overall publication activity of the Community. The strictly legal texts with "geology" + "soil" + "geophys" + "mineral" have a more constant trend, with peaks in mid 1970s, a depression in the mid 1990s, and a moderate but permanent increase since then. In a broad sense and over the 50-year average, geoscience related ones represent about $10-15 \%$ of the EU legal documents.

\section{Discussion}

The historical review of EU Community legislation with regard to the regulated topics relevant to geology, and geosciences in a broader context, as well as the quantitative output of word search in EURLEX show similar results. In the 1970-80s the relevant acquis was limited to exploration, production, stocks and trade of fossil fuels, workers safety and health. In the 1970s an equal number of documents dealt with geology as environment. The earliest pieces on environment were on dangerous chemicals, waste management and water, and the extractive industry was excluded from their scope. The environmental field came into focus in the 1990s, due to the Amsterdam Treaty.

At the turn of the century, due to numerous accidents related to tailings dam failures the extractive sector was brought into the scope of environmental legislation, and a set of legislation was published on extractive waste management. Parallel to this, the energy policy progressed and reached the level of law making, also in line with the decarbonization efforts due to global climate agreements. During the last 20 years, the scope of the environmental acquis extended to almost all environmental compartments, with the exception of soil and subsoil, and also to major emitting sectors and waste streams. It is remarkable that the proportion of these policy and regulatory fields in the total EU document "production" is continuously increasing.

Since 2000 , the strictly geology-related and the broader environment curves correlate fairly well, indicating that the policy fields of geology are much related to environmental affairs. In the last decade several policy documents were published on raw materials, resource efficiency, circular economy, and unconventional hydrocarbons, but these topics have not been manifested in legislation.

The embedding of the rules of a discipline and profession such as geology into national and/or supranational legislation framework is of paramount importance. This is little known to geologists employed in academic research, but the Community allocates significant funding for research and innovation in support of the new policy fields which should raise awareness. The topic is more familiar to chartered geologists working in the business sector, who have to comply with legal requirements during their daily routine. Beyond these two groups, this study also addresses colleagues at the government sector and at the international organisations by providing a historical snapshot and a future outlook on how this field is regulated in the EU.

Re-industrialization of Europe and deregulation were priorities of the Juncker Commission (2014-2019). Nevertheless, the number of geology and environment related legal documents shows a continuous increase. In the Green Deal natural capital services, including a reinforced soil policy, toxic-free environment, critical raw materials, renewables are core topics. However, policy objectives are not necessarily manifested in legal documents. This was the case with the draft Soil Framework Directive and the raw materials policy, although the latter are national assets and excluded from the scope of Community legislation according to the Treaty of the Functioning European Union (TFEU).

The strengthened climate policy and related de-carbonisation may rejuvenate the CCS efforts, the utilization of geothermal resources, 
and the enhanced use of geospace for energy storage. The prevention and mitigation of geohazards has relatively few provisions in the acquis.

Water and groundwater related attention is increasing continually, and extending towards the marine environment. Waste landfilling, a traditional area for geologists, is phasing out. Still, the extractive waste management remains a developing field. The scope of waste management has been significantly shifted to waste recycling and recovery of secondary raw materials, and circular economy is a core element of the Green Deal.

Spatial development and land use planning are not excluded explicitly from the TFEU scoping but all attempts to cover these aspects failed due to the opposition by MS by referring to the subsidiarity principle. Nevertheless, the Strategic Implementation Plan of the European Innovation Partnership on Raw Materials (EC, 2013) calls for introducing 3D spatial planning in all MS.

The traditional fields of fundamental academic geological research, non-fuel minerals exploration, cultural and scientific heritage are not covered by the acquis. In the future it is very likely that they will be dealt with by the sovereign jurisdiction of the MS' national legislation. Often, legislation is driven by political interests generated by abruptly emerging public attention and pressure, as happened a few years ago in the case of unconventional hydrocarbons and hydraulic fracturing. The momentum in that case was not sufficient to spur legislation but in other cases the final outcome may be different.

Globalisation of the economy and the increased codification of geologists' work will continue to boost professional mobility of geoscientists. However, because of cultural and legal differences and the extent to which the practice of geoscience is considered to impact society within a country jurisdiction, systems that are based on mandatory registration or licensing limit geoscientists' mobility. In contrast, the award of professional titles and voluntary registration, operated by professional geoscience organisations and with assessment by peers, is more effective in the facilitation of professional mobility, as justified by business players through their demand or relative preference on professional title holders at work contracts, and demonstrated by the EurGeol title in Europe and in the rest of the world.

Alongside peer review competence, the voluntary adherence to a Code of Ethics and submission to disciplinary powers are crucial factors for the international recognition of these titles. This places personal and professional integrity on centre stage, in line with the growing importance of geoethics. The International Association for the Promotion of Geoethics (http://www.geoethics.org), is a multidisciplinary scientific platform which is for widening the discussion and creating awareness about problems of ethics applied to the geosciences. Its website provide an exhaustive list of references on this topic.

\section{Conclusions}

Geological aspects and related duties of geologists are embedded into numerous sector-specific legislation of the European Union. In a broad sense, geology related topics present ca. $14.5 \%$ of the EU legal documents. The founding treaties of the European Coal and Steel Community and Euratom provide rules related mainly to the fossil fuels extractive industry. In the last decade of the twentieth century, environment, water and waste management regulatory fields entered the Community domain and addressed geological issues. Tailings accidents at the turn of the century changed the regulatory scene, the extractive sector was brought to the scope of environmental directives. The energy policy and de-carbonisation, the raw materials and the circular economy policies generated new tasks for geoscientists over the last twenty years. The Professional Qualifications Directive acknowledges geology as a regulated profession and ensures the mobility of geologists across MS.

The piece-by-piece historical review of EU Community legislation in the last half century, as well as the quantitative figures of EU legal documents are indicative of the growing duties of geologists, and geoscientists. The 50-year trend shows a convincing permanent increase with a well-established estimate that this trend will continue over the Green Deal program period.

\section{Acknowledgement}

The authors express their gratitude to all geologist colleagues who understand that legislation can ensure the long term health of this discipline, in the interests of a modern, sustainable society and economy. Maria Hamor-Vido is particularly grateful for the Fund EFOP-3.6.1.16-2016-00004 at University of Pécs for its support. David Fenerty significantly improved the English style of the text, and the anonymous peer reviewers assured the professional quality of the article.

\section{Disclaimer}

The views expressed are purely those of the authors and may not in any circumstances be regarded as stating an official position of the European Commission.

\section{References}

Allington, R., Fernandez-Fuentes, I., 2014, The Roles and Responsibilities of Engineering Geologists and Other Geoscientists in Serving Society and Protecting the Public - an Overview of International Approaches to Ensuring Effective and Ethical Professional Practice. In: Engineering Geology for Society and Territory - v. 7, doi:org/ 10.1007/978-3-319-09303-1_25

Clifford, J., 2002, The European Geologist professional title. European Geologist, No. 14, pp. 16-19.

Cordiani, U. G., 2000: The role of the earth sciences in a sustainable world. Episodes, v. 23, pp. 155-162.

Di Capua G. and Peppoloni S., 2019, Defining geoethics. Website of the IAPG - International Association for Promoting Geoethics, http:// www.geoethics.org/definition, [accessed 4th February 2020].

European Commission, 2008, Communication from the Commission - The raw materials initiative: meeting our critical needs for growth and jobs in Europe. COM/2008/0699

European Commission, 2011a, Communication from the Commission - Tackling the challenges in commodity markets and on raw materials. $\mathrm{COM} /$ 2011/0025

European Commission, 2011b, Communication from the Commission - Roadmap to a Resource Efficient Europe. COM/2011/0571

European Commission, 2012, Communication from the Commission - Making raw materials available for Europe's future well-being, Proposal for a European Innovation Partnership on raw materials. COM/2012/082

European Commission, 2013, Strategic Implementation Plan of the Euro- 
pean Innovation Partnership on Raw Materials. https://ec.europa.eu/ growth/sectors/raw-materials/eip_en, [accessed $5^{\text {th }}$ February 2020].

European Commission, 2014a, Communication from the Commission on the exploration and production of hydrocarbons (such as shale gas) using high volume hydraulic fracturing in the EU. COM/2014/023

European Commission, 2014b, Commission Recommendation on minimum principles for the exploration and production of hydrocarbons (such as shale gas) using high-volume hydraulic fracturing. 2014/70/EU

European Commission, 2014c, Communication from the Commission - On the review of the list of critical raw materials for the EU and the implementation of the Raw Materials Initiative. COM/2014/0297

European Commission, 2014d, Communication from the Commission - Towards a circular economy: A zero waste programme for Europe. COM/2014/ 0398

European Commission, 2015, Communication from the Commission - Closing the loop - An EU action plan for the Circular Economy. COM/2015/ 0614

European Commission, 2017a, Report from the Commission on the implementation of the Circular Economy Action Plan. COM/2017/0331

European Commission, 2017b, Communication from the Commission - The role of waste-to-energy in the circular economy. COM/2017/034

European Commission, 2017c, Legal framework for mineral extraction permitting procedures for exploration and exploitation in the EU, "The MINLEX study"

European Commission, 2018, Communication from the Commission - A European Strategy for Plastics in a Circular Economy. COM/2018/028

European Commission, 2019, Communication from the Commission The European Green Deal. COM/2019/640

Goodman, R., Pasquali, R., Dumas, P., Hámor T., Jaudin F., Kepinska, B., Reay, D., Rueter, H., Sanner, B., Van Heekeren, V., Bussmann, W., and Jones, G., 2010, GTR - H - Geothermal Legislation in Europe. Proceedings World Geothermal Congress 2010 Bali, Indonesia, p. 8.

Hámor, T., 2002, Legislation on mining waste management in Central and Eastern European Countries. Joint Research Centre, Ispra, EUR 20545 EN, 188 p.

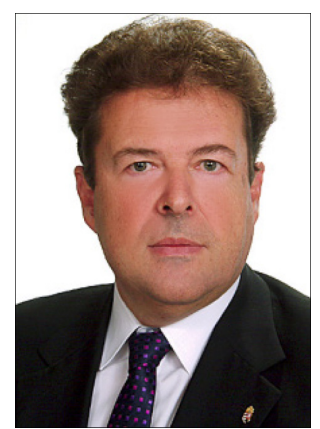

Tamas Hamor is a PhD geologist mining engineer with degrees in law and economics, an honorary associate professor. He served the Geological Institute and the Hungarian Office for Mining and Geology for 32 years, since 2005 as a Head of Unit. In 2016 he was recruited by the Joint Research Centre of the European Commission. He was the Board Member of the European Federation of Geologists, the Geological Society of Hungary, and the Hungarian Geothermal Association.

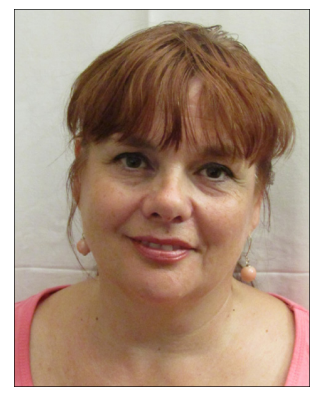

Maria Hamor-Vido is a PhD geologist mining engineer, an expert in fossil fuels geology and exploration, specialized in organic petrography. She worked at the Geological Institute and at the Geophysical Institute of Hungary for 32 years, she functioned as a deputy director between 2010-2014. Since 2016 she has been an associate professor at the University of Pécs. She was the President of the Earth Sciences Section of the Hungarian Science Society, and in 2019 she became the Secretary General of the International Committee for Coal and Organic Petrology.
Hámor, T., 2004a, The last environmental medium: A mapping of the European Union Community legislation with regard to provisions on soil. Joint Research Centre, Ispra, EUR 21063 EN, 55 p, ISBN: $92-$ 894-5171-9

Hámor, T., 2004b, Sustainable mining in the European Union: The legislative aspect. Environmental Management, v. 33, pp. 252-261.

Hámor, T., 2014, Legal duties of EuroGeologists in the past, and future vision according to the ERA-MIN Roadmap. EFG Workshop "Geologists of Europe in the $3^{\text {rd }}$ Millenium", Palermo, Programme and Abstracts, p. 8.

Hámor, T., 2016, Geology, the regulated discipline in Europe - a historical review and a vision. 35th International Geological Congress, Cape Town, Abstracts.

Manfredi, S., Hamor, T., Wittmer, D., Nuss, P., Solar, S., Latunussa, C., Tecchio, P., Nita, V., Vidal Legaz, B., Blengini, G., Mancini, L., Torres de Matos, C., Ciuta, T., Mathieux, F., and Pennington, D., 2017, Raw Materials Information System (RMIS): towards v2.0 - An Interim Progress Report \& Roadmap. Publications Office of the European Union, 100 p, ISBN: 978-92-79-66932-3

Official Journal of the European Union, 2020, https://eur-lex.europa.eu/oj/ direct-access.html; [accessed $5^{\text {th }}$ February 2020].

Peppoloni S. and Di Capua G., 2017, Geoethics: Ethical, Social and Cultural Implications in Geosciences. In Geoethics at the Heart of all geoscience. Annals of Geophysics, v. 60(7). doi:org/10.4401/ag-7473

Stoker, P., 2014, The CRIRSCO Template and the Competent Person. 2014 CRIRSCO Meeting China Mining Tianjin, http:/www.crirsco. com/docs/3_CRIRSCO_Template_and_Competent_Person_P_Stoker.pdf, [accessed $5^{\text {th }}$ February 2020$]$.

Vidal, O. et al., 2013, ERA-MIN Research Agenda. ERA-MIN, Paris, 124 p., https:/www.era-min.eu/sites/default/files/publications/era-min_research agenda.pdf, [accessed $5^{\text {th }}$ February 2020].

Toth, A., 2017, The Geothermal Atlas of Hungary. Hungarian Energy and Public Utility Regulatory Authority, ISBN 978-963-12-849-1

VERAM, 2018, Research Roadmap and Recommendations, http://veram 2050.eu/wp-content/uploads/2018/10/D5.2-RM-Research-Roadmapand-recommendations.pdf [accessed 4th February 2020].

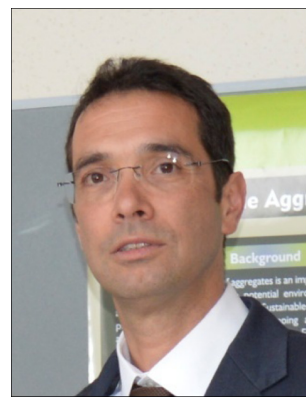

Vitor Correia is Secretary-General of the International Raw Materials Observatory and Past-President of the European Federation of Geologists. He founded and managed several companies working in geosciences, and he has over 25 years of experience in strategic management, innovation and organizational effectiveness. He began his career as a mining geologist, and he worked in mineral exploration, geological engineering and environmental geology in Europe, Africa and South America. Vitor holds a BSc in Geology and an MBA, both from the University of Lisbon. $\mathrm{He}$ is registered as a EuroGeol. 